\title{
Induced Differentiation of Epithelioid Carcinoma Cell Lines: Evidence for Tumor Cell Quantal Mitosis
}

\author{
John J. Wille*, Jong Y. Park \\ Department of Cell Biology, Southern Research Institute, Birmingham, AL, USA \\ Email: *jjwille@aol.com
}

How to cite this paper: Wille, J.J. and Park, J.Y. (2016) Induced Differentiation of Epithelioid Carcinoma Cell Lines: Evidence for Tumor Cell Quantal Mitosis. Journal of Cancer Therapy, 7, 794-811.

http://dx.doi.org/10.4236/jct.2016.711080

Received: April 19, 2016

Accepted: October 28, 2016

Published: October 31, 2016

Copyright $\odot 2016$ by authors and Scientific Research Publishing Inc. This work is licensed under the Creative Commons Attribution International License (CC BY 4.0).

http://creativecommons.org/licenses/by/4.0/

\section{(c) (i) Open Access}

\begin{abstract}
The effects of growth factors and calcium concentrations present in different culture media on induction of terminal differentiation were investigated for four different epidermoid carcinoma cell lines, Hela, KB, A431, and SCC-25, and their responses determined relative to those elicited by normal human keratinocytes subjected to these culture conditions. Differentiation status was determined cyto-chemically by a validated keratin protein staining method, and by autoradiographic analyses. Growth and differentiation promoting factors that influenced the direction of integrated control of growth and differentiation in normal human keratinocytes were found to be effective for some cell lines but not others. The factors examined were 1) high density arrest in serum-free and serum-containing media, 2) media shifts from high density culture in serum-containing media to low density growth factor-depleted or supplemented serum-free medium, and 3) the concentration of calcium in the media. The extent and degree of differentiation achieved varied among different cell lines depend on the presence or absence of serum, EGF and insulin protein growth factors. Certain growth media appear to sponsor keratin protein, cyto-chemicallydetected differentiation, and evidence of quantal mitotic division in low density HeLa cell and SCC25 cell cultures. Epidermoid carcinoma cell lines retain limited capacity to commit to early stages of cell differentiation.
\end{abstract}

\section{Keywords}

Cell Differentiation, Epidermoid Carcinoma Cell Lines, A431, Hela, Kb, SCC-25

Keratinocytes, Cytochemical Staining Methods, Quantal Mitosis

\section{Introduction}

The majority of human tumors arise from epithelial tissues and are known as carcino- 
mas. Histo-pathological analyses of these cancerous tissues reveal that they harbor a population of undifferentiated cells that continue to proliferate under conditions that restrain normal cells from dividing. This subpopulation of proliferating cells is now recognized to arise from the stem cells of origin of the tissue that have lost the ability to undergo irreversible tissue type differentiation [1]. Earlier experimental studies reported that the architecture of normally developing keratinocyte colonies cultured in vitro assumed a structure with the dividing cells located at the colony periphery and histologically-differentiated cells located in the colony interior [2]. They also reported that kereatinocytes infected with simian virus 40 (SV-40) displayed a drastic restructuring of developing keratinocyte colonies with an profound increase in the proliferative monolayer cells at the periphery and a much reduced multilayered layer differentiation cells present in the colony interior. This demonstration was achieved using Ayoub and Shklar's (A \& S) modification of Mallory's Trichrome staining method [3], whereby keratin proteins (KP) stained a red color and by autoradiography. The former method was validated as a method for detecting keratinocyte differentiation by comparing its specificity with an involucrin antibody and by KB antibody, a specific epidermal differentiation marker detected by indirect immunofluorescense microscopy [4]. In fact, the cytochemical method was found to be the more sensitive. Later, Fusenig et al. [5] reported altered morphology of transformed human keratinocytes and related them to different degrees of differentiation rather than different stages of malignancy.

Serum and plasma are complex mixtures of growth promoting and differentiation inducing factors. We previously reported that citrated human platelet-poor plasma induces adipocyte differentiation in a mouse embryonic fibroblast cell line [6]. We showed for NHK cells that a prerequisite for differentiation was growth arrest at a unique $G_{1}$ phase restriction point in the cell cycle [6]. Further studies showed that tumorigenicity is suppressed in clones of $3 \mathrm{~T} 3 \mathrm{~T}$ proadipocytes that maintain the ability to control both proliferation and differentiation [7]. With the development of sophisticated chemically-defined serum-free media and the role of defined protein growth factors regulating proliferation, growth arrest and differentiation have been clarified for normal human epidermal keratinocytes [8] [9]. Here we investigate the effect of modulating culture media and growth factors in inducing keratinizing stratified terminal differentiation of proliferating cultures of HeLa, KB, SCC25 and A431 epidermoid carcinoma cell lines in contrast to their effects on growth and differentiation responses of normal human keratinocytes (NHK).

\section{Methods and Materials}

\subsection{Cell Culture}

Human epidermal keratinocytes culture were prepared from neonatal foreskin tissue samples and grown in culture in growth $\mathrm{f}$ actor (EGF, $5 \mathrm{ng} / \mathrm{ml}$ and insulin, $5 \mathrm{mg} / \mathrm{ml}$ ) supplemented serum-free MCDB 153 medium prepared in house as previously described [8]. HeLa, KB, A431 and SCC25 cells are model cell lines of epidermoid carcinoma origin were obtained from cryopreserved stocks (Dr. Robert E. Scott, Mayo Med- 
ical School, Rochester, MN). Both HeLa cells and $\mathrm{KB}$ cell lines were originally derived from cervical epithelial type carcinomas. A431 cell line was derived from an epidermoid carcinoma. SCC25 cell line derived from a minimally differentiated nasopharyngeal tumor was a gift from Dr. James Rheinwald, Harvard Medical School (Boston, MA). HeLa, $\mathrm{KB}$, and A431 were routinely maintained in Dullbeco's modified minimal essential medium (DMEM) supplemented with 10\% (vol/vol) fetal calf serum (FCS) (GIBCO, NY). SCC25 was maintained in a 50:50 mixture of DMEM: F12-5\% FCS. For passage, cultures all cultures were trypsinized when subconfluent and replated in DMEM-10\% FCS or DMEM: F12: 5\% FCS. For experiments involving media transfers cultures growing in a serum-containing media, the spent media was aspirated off, and the cell cultures washed twice with ice-cold 1XPBS (phosphate buffed saline). The cells were then trypsinized and replated in fresh test medium according to previous methods [8].

\subsection{Staining of Cells for Keratin Proteins}

Formalin-fixed cells were stain for keratin proteins by the water-soluble temporary keratin protein stain of A \& S Trichrome method [3], modified for in vitro epidermal keratinocyte cultures [5] [7]. It uses acid fuchsin followed by and Orange G/analine blue counter stain as previously described. When the procedure applied to formalin-fixed paraffin sections of human epidermis, it stains the basal layer of undifferentiated kereatinocytes blue, the suprabasal keratinocytes stain a mixture of orange and red cells, the granular later of keratinocytes are stained red, and the corneocytes of the squamous stratified layer a silver grey or black color. Previously, we described the uses of BK, a fluoroscein-conjugated monoclonal antibody specific for keratin protein only present in undifferentiated keratinocytes that validate the ascription of blue stain for undifferentiated cells and red cells as keratin protein differentiated keratinocytes [8].

\subsection{Autoradiography}

Normal human keratinocytes (NHK) cultures were plated on coverslips and incubated in culture medium containing $2 \mu \mathrm{Ci}$ of $\left[{ }^{3} \mathrm{H}\right] \mathrm{TdR}$ per $\mathrm{ml}(20-40 \mathrm{Ci} / \mathrm{mol}$, New England Nuclear) for 24 hours and processed for light microscopic autoradiography as previously described [8].

\subsection{Cytofluorometry}

The DNA content of NHK was determined by flow microfluorometry (FMF) according to the previously described procedures [10]. The DNA stain employed was mithramycin $(1 \mathrm{mg} / \mathrm{ml})$. The DNA content of stained cells was measured with Beckton-Dickson FACS IV instrument. Cell cycle analysis of frequency histograms for the distribution of DNA content was carried according to a especially designed computer program [10].

\section{Results}

\subsection{Integrated Control of NHK Proliferation and Differentiation}

Earlier, we reported that low calcium concentration supported sustained proliferation 
of human keratinocytes in serum-free MCDB153 medium [8]. Cultures were plated in complete MCDB153 medium and fixed and stained with crystal violet stain after 4 days of clonal culture, and the a average number of cells per colony counted by light microscopic examination. The effect of different combinations of EGF and calcium concentrations on the colony counts was presented (Figure 1). Growth was negligible in the absence of EGF at all calcium concentrations. At $0.1 \mathrm{ng} / \mathrm{ml}$ of EGF colony sizes were inversely proportional to calcium concentration with a maximum of 14 cells per colony at $0.03 \mathrm{mM}$ calcium and 8 cells per colony at $1.0 \mathrm{mM}$ calcium. This pattern was observed again for $1.0 \mathrm{ng} / \mathrm{ml}$ and $10 \mathrm{ng} / \mathrm{ml}$ EGF.

\subsection{KP Staining and Autoradiography of Undifferentiated and Differentiated NHK Keratinocytes}

Low density cultures of basal NHK cells were grown differently in complete MCDB 153 medium containing either low calcium $(0.1 \mathrm{mM})$ (Figure $2(\mathrm{a})$ ) or high calcium $(2 \mathrm{mM})$ (Figure 2(b)). When counterstained for KP, all stained blue. Autoradiographic analysis shows that $>95 \%$ of the nuclei in blue-stained cells were labeled for DNA synthesis in either low calcium SFM (Figure 2(a)) or high calcium SFM (Figure 2(b)), independent of colony morphology. Figure 2(c) shows a colony that was shifted on day 1 to a high calcium protein growth factor-depleted media and labeled for detection of DNA synthesis for 24 hours 2 days after media shift after autographic processing and counter-stained for KP. A profound alteration of colony structure was observed. Undifferentiated monolayer of keratinocytes that stain blue lie 2 - 3 cells thick along the colony periphery stain blue and the majority of their nuclei are labeled for DNA synthesis. The interior of the colony is composed entirely of unlabeled orange stained stratified cells. Figure 2(d) shows a large colony that was counter-stained with KP, 6 days after a low density proliferating NHK culture first grown in a low calcium $(0.1 \mathrm{mM})$ complete MCDB 153 medium was shifted to high calcium (2 mM) standard medium lacking EGF and insulin. The periphery of undifferentiated monolayer cells were stained blue. By

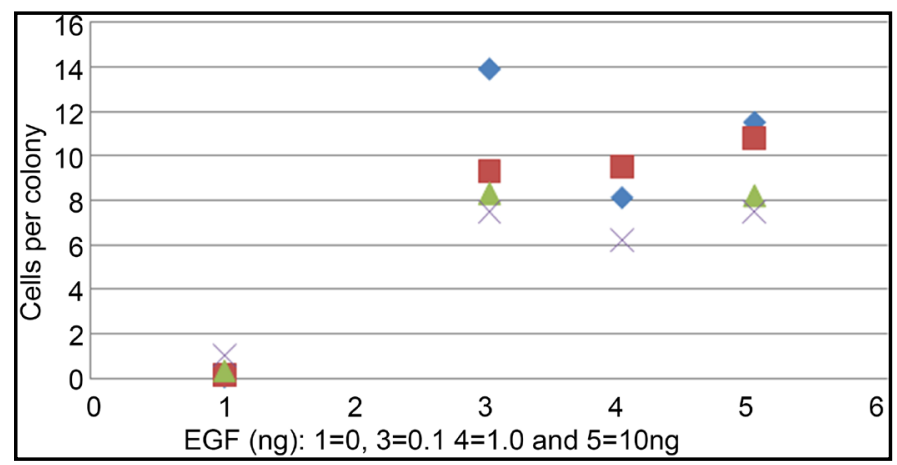

Figure 1. Effect of varying concentration of EGF in combination with calcium on clonal growth of NHK. Triplicate dishes were stained with crystal violet. Values given are $\pm 10 \%$ of means Ordinate: average number of cell per colony as determined by counting colonies from ten random fields with an ocular micrometer. Abscissa: calcium concentration $(\mathrm{mM})$ for each data point: 0.03-blue, 0.1-red, 0.3-green, and 1.0-X. 


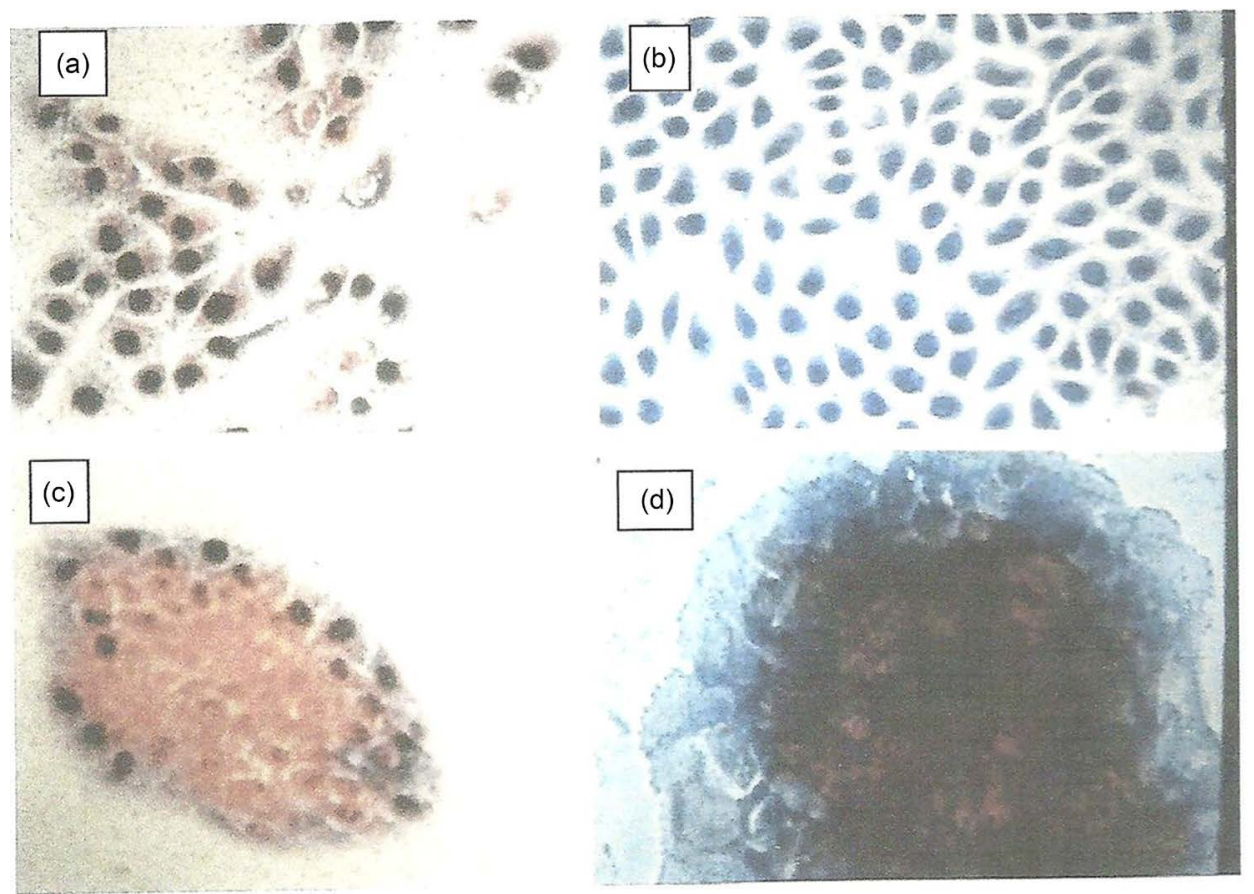

Figure 2. Low density-low calcium NHK culture (a), and low density-high calcium NHK culture (b) both grown in MCDB $153 \mathrm{SFM}$ with EGF ( $5 \mathrm{ng} / \mathrm{ml})$ and insulin $(5 \mu \mathrm{g} / \mathrm{ml})$ additions, post-stained with KP stain after 24 hour $\left[{ }^{3} \mathrm{H}\right]$-thymidine labeling and subsequent autoradiographic preparation; (c) low density-high calcium NHK culture grown in MCDB 153 SFM medium lacking growth factors for 2 days and post-stained with KP stain after $\left[{ }^{3} \mathrm{H}\right]$-thymidine pulse-labeling for 24 hours and subsequent autoradiographic preparation; (d) same treatment as (c) without radiolabelling. All cultures were stained with KP stain (see methods).

contrast, the entire stratified interior of the colony stains red, as previously described [5] [8].

\subsection{Effect of Growth Factor and Media Manipulations on Hela Cell Differentiation}

Sub-confluent proliferating cultures of HeLa cells that are serially cultured in DMEM-10\% FCS media show little evidence of spontaneous differentiation observed either by routine phase contrast microscopy and blue stain of the cultured cells by the KP strain. Figure 3(a) shows a culture that has reached confluent cell density in this serumcontaining medium. Evidence of early stages of differentiation is a minor (5\% - 10\%) population of cells that stain red-orange in focal areas of stratification (prekeratin), a situation often observed in post-confluent NHK cultures.

We tested the effect of switching a low-density proliferating HeLa cell cultures to medium lacking serum. HeLa cells were replated at low density $\left(10^{3}\right.$ cells $\left./ \mathrm{cm}^{2}\right)$ into fresh DMEM medium without serum. Figure 3(b) shows that a large scale induction of cell differentiation did not occur 9 days after culture in DMEM containing $2 \mathrm{mM}$ calcium. There was significant cell growth and $>95 \%$ of all cells stained blue. However, a small number of red-stained pairs of cells were evident (see arrow) with the KP stain. 
This shows that HeLa cells in the short run do not require serum to proliferate and the majority cells continue to remain undifferentiated in a serum-starved state. Nevertheless, the cells were smaller and grew in clustered colonies. The latter is reflective of the effect high calcium media has on proliferating NHK cultures. We next investigated the effect of growing HeLa cells in a DMEM supplemented with EGF and insulin, two protein growth factors required for NHK culture. Figure 3(c) shows that there was significant cell proliferation with many mitotic figures after 12 days of culture growth, and all cells stained blue stain with the KP stain. Morphologically, HeLa cells appeared typical of undifferentiated HeLa cells growing in DMEM-10\% FCS.

We next tried to induce keratinizing differentiation of HeLa cells by growing them in DMEM-10\% FCS, and then replating them at low density $\left(10^{3} \mathrm{cells} / \mathrm{cm}^{2}\right)$ in low calcium (0.1 mM) MCDB 153 SFM lacking protein growth factors. Figure 4(a) shows that cell growth was minimal after 5 days and all cells stained blue with the KP stain. Keratinizing differentiation did not occur under these conditions. Figure 4(b) shows that HeLa cells grown in DMEM-10\% FCS and replated at low density in high calcium (2 mM) MCDB153 SFM medium lacking protein growth factors failed to induce keratinizing differentiation. Morphologically, the HeLa cells resembled proliferating HeLa cells grown in DMEM-10\% FCS. Figure 4(c) shows the result when HeLa cell culture growing in DMEM-10\% FCS and then replated at low density in low calcium $(0.1 \mathrm{mM})$ MCDB153 medium supplements with EGF ( $5 \mathrm{ng} / \mathrm{ml}$ ) and insulin $(5 \mathrm{mg} / \mathrm{ml})$ for 5 days exhibited a remarkable induction of red-stained cells indicating efficient induction of commitment to keratinizing differentiation. Figure 4(c) was analyzed to determine the number of red and blue cells. Out of 100 cells in the field, there were almost an equal number of blue ( $\mathrm{N}=48,48 \%$ cells $)$ and red $(\mathrm{N}=52,52 \%$ cells). Often we observed that a red cell is paired with a blue cell, suggesting that a mother cell may have undergone a quantal-type mitotic division yielding a pair of undifferentiated and a differentiated daughter cell. Figure 4(d) shows that when a proliferating HeLa cell culture growing in DMEM-10\%FCS is plated at low density in high calcium (2 mM) MCDB153 supplemented with EGF $(5 \mathrm{ng} / \mathrm{ml})$ and insulin $(5 \mathrm{mg} / \mathrm{ml})$, there is a profound and efficient induction of commitment to keratinizing differentiation. Figure 4 (d) was analyzed to
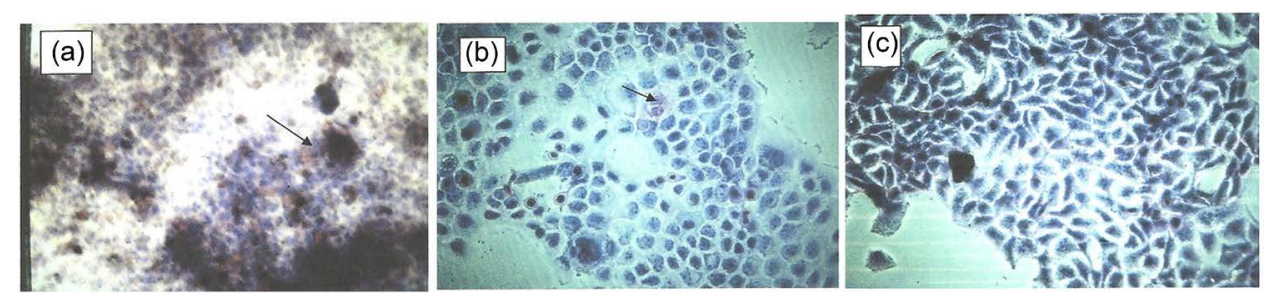

Figure 3. Effects of growth factor and media manipulations on HeLa cell differentiation. HeLa cells were cultured in DMEM medium plus or minus serum or protein growth factors. (a) DMEM $+10 \%$ FCS for 9 days. Note: orange-red stained nuclei and red-black stained differentiated foci (see arrow); (b) sub-confluent cultures in DMEM medium depleted of serum. Note: pink-red stained pairs of cells (see arrow); (c) DMEM medium supplemented with EGF ( $5 \mathrm{ng} / \mathrm{ml}$ ) and insulin $(5 \mu \mathrm{g} / \mathrm{ml})$. Note: all blue cells and absence of differentiation in sub-confluent cultures. All cultures were stained with the KP stain (see Methods). 

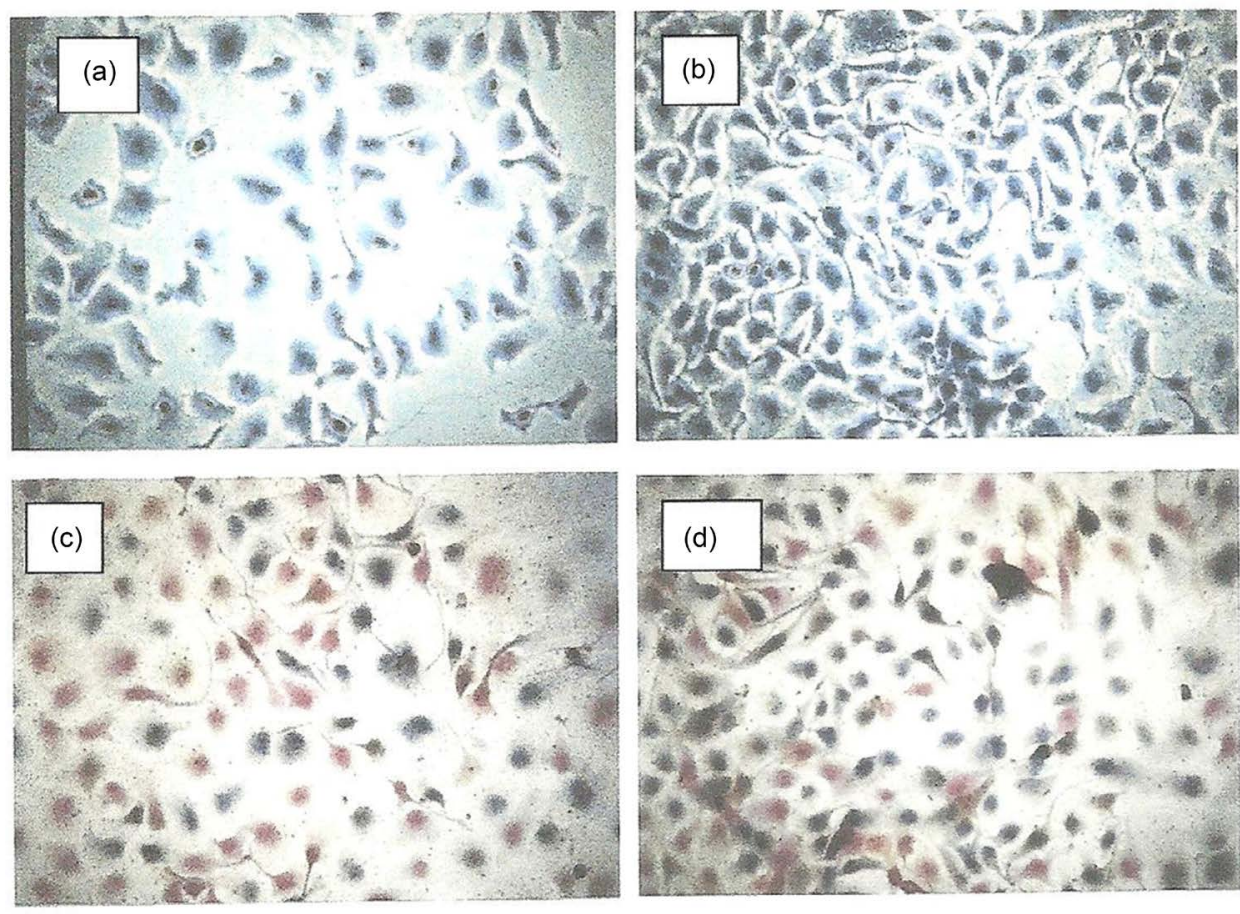

Figure 4. Low density-low calcium culture of HeLa cells grown in MCDB 153 SFM lacking serum or protein growth factors (a); (b) HeLa cells grown in low density-high calcium MCDB 153 SFM lacking protein growth factors; (c) and (d) note: keratinizing differentiation (red cells) occurs when HeLa cells are cultured in either low calcium (c) or high calcium (d) MCDB SFM supplemented with EGF $(5 \mathrm{ng} / \mathrm{ml}$ ) and insulin $5 \mu \mathrm{g} / \mathrm{ml}$ ). All cultures were stained with the KP stain (see Methods).

determine the number of red and blue cells. Out of total of 139 analyzable cells in the field, there were approximately twice the number of blue $(\mathrm{N}=92.67 \%$ cells $)$ than red cells $(\mathrm{N}=47.33 \%$ cells $)$.

\subsection{Keratin Protein Staining of Kb Cells Cultures in DMEM-10\% Fcs}

$\mathrm{KB}$ cell line was originally re-isolated from a HeLa cell line as an epitheloid-type derivative. When cultured in DMEM-10\% FCS the culture displays tightly packed cuboidal morphology typical of an epitheloid carcinoma cell line, and reminiscent of normal keratinocytes monolayer morphology. Figure 5(a) is images of a culture grown in DMEM-10\% FCS for 5 day fixed and stained with the KP stain. The periphery of each colony several cell diameters thick stains blue, indicative of undifferentiated cells, and many of the smaller colonies are composed entirely of blue stained cells. The interior of the larger colonies have foci of stratified red-stained cells, an architecture similar to that of normal keratinocyte colonies undergoing terminal keratinizing differentiation induced by growth factor depletion (see Figure 2). Figure 5(b) show a 9 day old post-confluent KB culture stained with the KP stain. There are many large stratifying foci of red cells overlain by large black stained cells. Black staining is due to uptake of phosphotungstic acid, an ingredient of the Ayoub and Shklar stain, which preferentially stains cornified 
squamous cells black. The results show that $\mathrm{KB}$ cultures have a greater propensity to spontaneous undergo commitment to keratinizing stratified squamous differentiation relative to NHK grown under high calcium (2 mM) SFM MCDB 153 supplemented with EGF and insulin.

\subsection{KP Staining of KB Cultured in Serum-Free Media Supplemented with or without Protein Growth Factors}

Figure 5(c) shows a culture of KB cells first grown in DMEM-10\%FCS, then replated at low density $\left(10^{3}\right.$ cells $\left./ \mathrm{cm}^{2}\right)$ in DMEM medium without EGF $(5 \mathrm{ng} / \mathrm{ml}) /$ insulin $(5 \mathrm{mg} / \mathrm{ml})$ and cultured for 3 days, fixed and stained with the KP stain. Under these conditions the cells continue to proliferate, and the majority is stained blue as expected for undifferentiated cells. Nevertheless a minority $(10 \%-20 \%)$ of KB cell underwent stratifying kereatinizing differentiation as seen by appearance of several foci of red-stained cells. Figure 5(d) shows a culture of KB cells shifted from DMEM-10\% FCS to DMEM medium lacking growth factors or serum and cultured for 8 days, fixed and stained with KP stain. The confluent monolayer of undifferentiated $\mathrm{KB}$ cells stains blue indicate continued proliferation. There is a minority $(5 \%-10 \%)$ of $\mathrm{KB}$ cells that formed a focus of stratified blue cells overlying red stained cells. Prolonged confluent culture in DMEM medium lacking growth factors or serum appears to suppress further keratinizing differentiation. KB cells grown in DMEM-10\% FCS and replated in DMEM supplemented with EGF (5 ng/ml) and insulin $(5 \mathrm{mg} / \mathrm{ml}$ ) induces massive squamous-keratinizing differentiation (Figure 5(e)). The monolayer exhibits peri-nuclear pinkish-red color evidence of developing keratin protein stain. In addition, the large cells of the stratified layer stain black indicating induction of cornified squames.

Figure 6 presents a panel of four images showing the effect of shifting a proliferating culture of KB cells growing in DMEM-10\% FCS to MCDB153 medium lacking serum or growth factors, (Figure 6(a) and Figure 6(b)) or with EGF and insulin (Figure 6(c) and Figure 6(d)) under low calcium $(0.1 \mathrm{mM}$ ) (Figure 6(a) and Figure 6(c)), and high calcium ( $2 \mathrm{mM}$ ) (Figures $6(\mathrm{~b})$ and Figure $6(\mathrm{~d})$ ). All cells were fixed and stained with the KP stain after 5 days of culture growth. There is little evidence of KB proliferation in conditions A and B. Cultures grown in MCDB153 low-calcium serum-free medium without EGF $(5 \mathrm{ng} / \mathrm{ml})$ and insulin $(5 \mathrm{mg} / \mathrm{ml})$ stained blue, indicating undifferentiated cells. However, under condition of high calcium medium lacking growth factors, no proliferation occurred and the cells stained red-black, indicating squamous keratinizing differentiation.

The majority of KB cells cultured in MCDB serum-free medium supplemented with EGF $(5 \mathrm{ng} / \mathrm{ml})$ and insulin $(5 \mathrm{mg} / \mathrm{ml})$ stained either red or blue in low calcium medium, and predominantly red-black in the high calcium medium with evidence of extensive red-stained cell stratification. Inspection of the later condition reveals many pairs of isolated cells with one red cell joined with one blue cell are again suggestive of quantal-type mitosis. The failure to undergo differentiation when $\mathrm{KB}$ cells are cultured in serum-free medium lacking growth factors is similar to the effect of growth factor and nutrient depletion conditions imposed on growing NHK cultures. Moreover, the in- 
duction of differentiation observed here when $\mathrm{KB}$ cells are cultured in high calcium serum-free MCDB 153 media supplemented with EGF $(5 \mathrm{ng} / \mathrm{ml})$ and insulin $(5 \mathrm{mg} / \mathrm{ml})$ are like those observed when NHK cells are cultured under the same media conditions. Unlike NHK cultures, KB cells cultured in serum-free medium supplemented with protein growth factors in a low calcium medium did undergo keratin protein differentiation as evidenced by both red and orange stained cells.
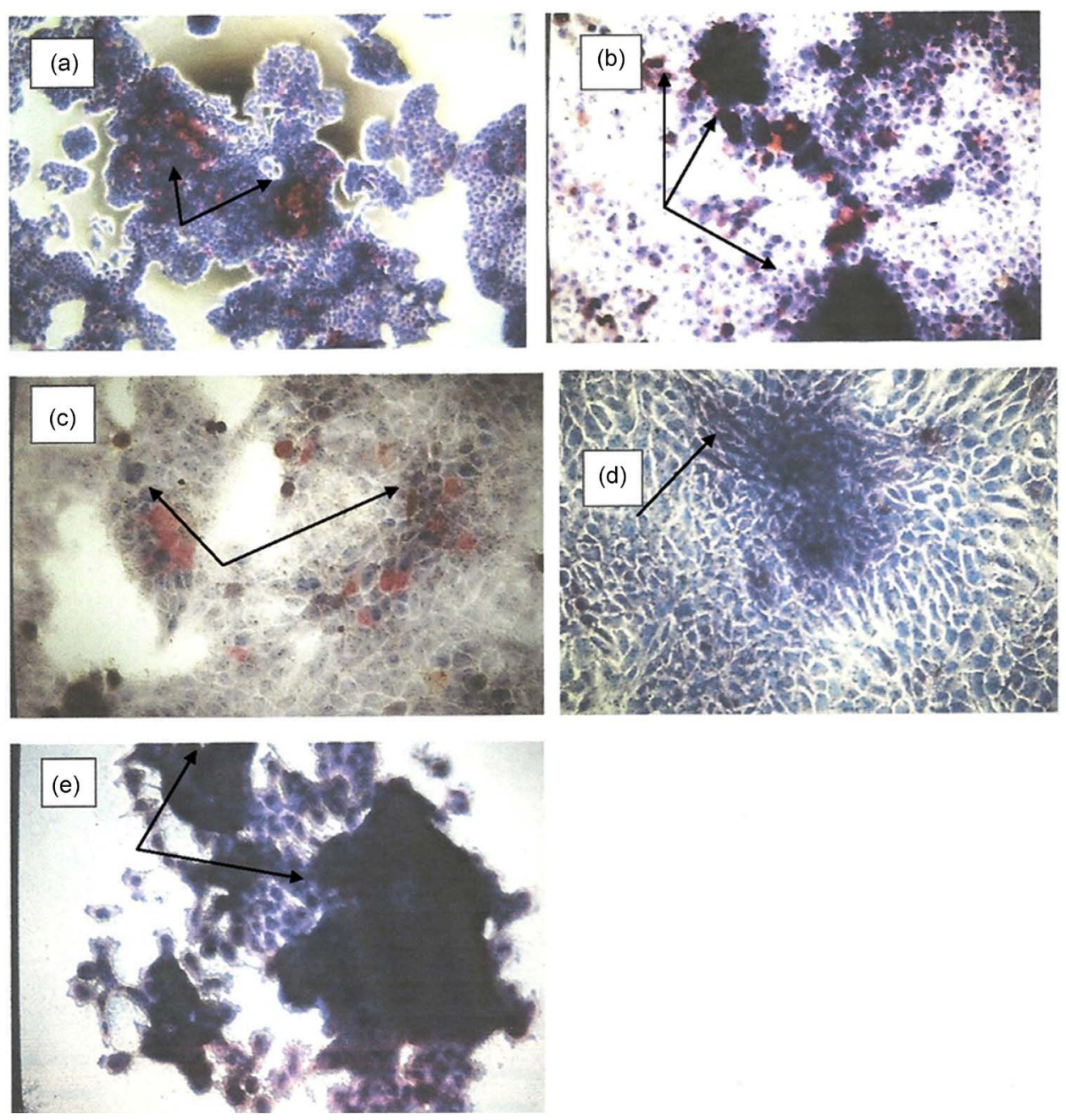

Figure 5. KB cells were cultured in DMEM-10\% FCS medium for 5 days (a). Note: stratified foci of red stained cells in the interior of the colonies surrounded by blue-stained cells at the colony periphery (see arrow); (b) 9-day old post-confluent culture of KB cells cultured in DMEM-10\% FCS medium. Note: foci of stratified red-stained cells and black cells, and peripherally-located blue-stained cells (see arrows); (c) 3-day old culture of KB cells grown in DMEM SFM without serum. Note: foci of stratified red-stained cells surrounded by a monolayer of blue-stained cells (see arrows); (d) 8-day old post-confluent culture of KB cells grown in DMEM medium without serum. Note: high cell density of monolayer with blue-stained foci of stratified keratinized cells (see arrow); (e) 12-day old sub-confluent KB culture grown in DMEM medium supplemented EGF $(5 \mathrm{ng} / \mathrm{ml})$ and Insulin $(5 \mu \mathrm{g} / \mathrm{ml})$. Note: stratified foci of keratinized black-stained cells identified as squamous differentiated KB cells (see arrows). All cultures were fixed and stained with KP stain (see Methods). 

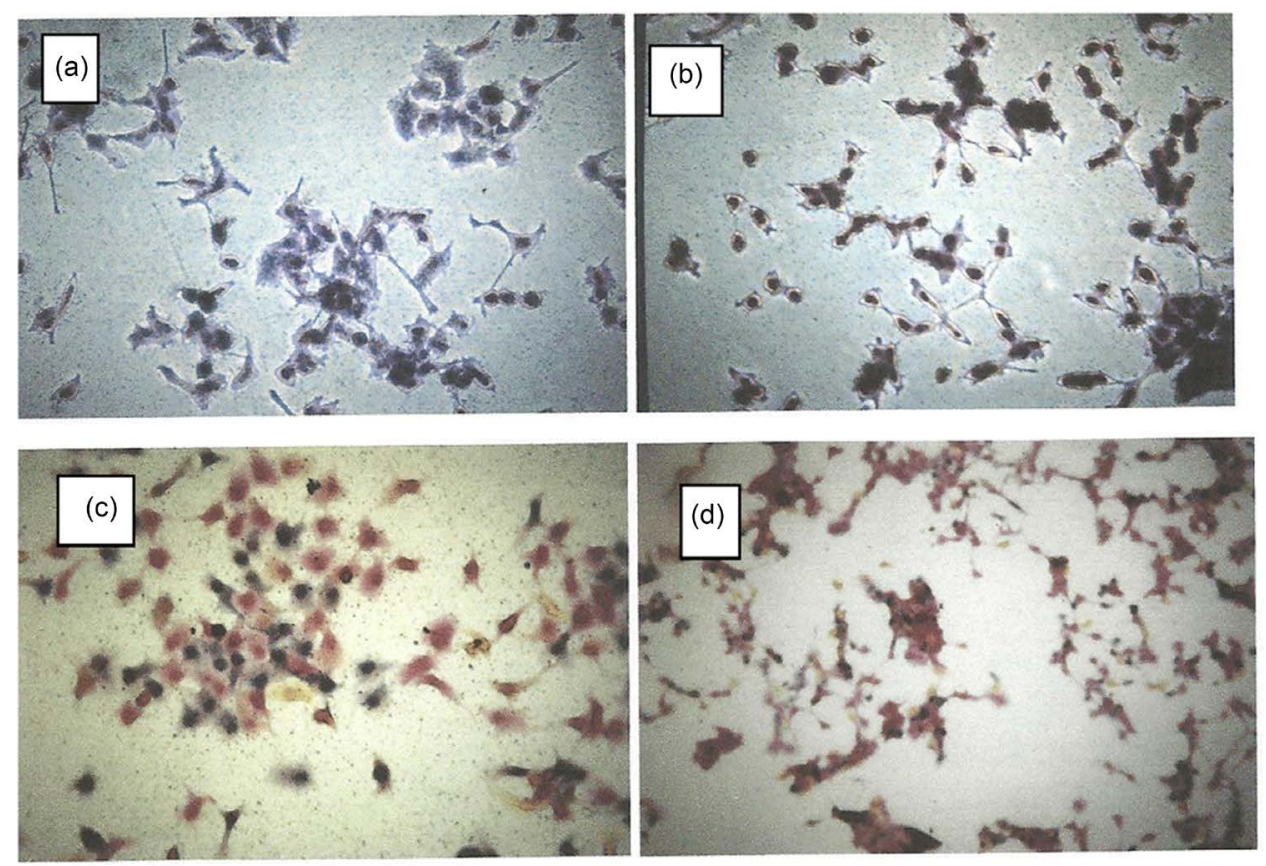

Figure 6. Four figures showing the effect of transferring a proliferating culture of KB cells growing in DMEM-10\% FCS to: (a) low calcium-low density MCBD153 SFM lacking serum or protein growth factors or to: (b) high calcium-low density MCDB153 SFM medium both lacking serum or protein growth factors. Note: clustering of blue-stained $\mathrm{KB}$ cells in low calcium medium due to protein deficiency and appearance of scattered black-stained cells in high calcium medium. KB cells cultured in low calcium (c) or in high calcium (d) MCDB 153 medium supplemented with EGF $(5 \mathrm{ng} / \mathrm{ml})$ and insulin $(5 \mu \mathrm{g} / \mathrm{ml})$. Note: high proportion of red-stained cells intermingled with high proportion of blue stained cells. (d) note: clustering of stratified red-stained foci with smaller proportion of blue-stained cells in high calcium medium. All cultures were fixed and stained with KP stain (see Methods).

\subsection{KP Staining of A431 Cells Cultured in Serum and Serum-Free Media Supplemented with or Lacking Protein Growth Factors}

Figure 7(a) shows a monolayer culture of A431 cells cultured in DMEM-10\% FCS for 5 days, fixed and stained with the KP stain. The majority of the monolayer is composed predominantly with undifferentiated blue-stained cells. Nevertheless, there is clear evidence of red-stained focal areas, some yellow-orange stained cells, and stratified foci of red-stained cells and scattered black-stained squames. These staining patterns are evidence for a spontaneous commitment to keratinizing differentiation in cultures reaching confluent cell densities. The red and yellow stained cells are larger than the blue cells, indicating their further progress toward keratinizing differentiation. Figure 7(b) show a post-confluent A431 culture propagated for 12 days in DMEM-10\% FCS, fixed and stained with KP stain. The majority are undifferentiated blue-staining monolayer cells, but a large proportion ( $>20 \%-40 \%$ ), form focal multilayered stratified areas that stain red, suggesting a propensity of A431 cell to undergo spontaneous keratinizing differentiation under high density proliferating conditions. Figure $7(\mathrm{c})$ shows A431 culture grown in DMEM-10\% FCS, and replated in DMEM medium lacking serum and 
cultured for additional 3 days, fixed and stained with the KP stain. Proliferation continued and the sub-confluent monolayer culture stained predominantly blue with evidence of a minority $(<5 \%)$ of scattered differentiated red -stained cells in interior of the colony; Figure 7(d) shows a confluent monolayer of A431 cells 8 days of culture in DMEM medium lacking serum or growth factors. The cells proliferated vigorously and stained blue indicating their undifferentiated state. Figure 7(e) shows a confluent monolayer monolayer of A431 cells 8 days of culture in DMEM medium lacking serum or growth factors. The cells of A431 cells cultured for 8 days in DMEM medium supplemented with insulin $(5 \mathrm{ug} / \mathrm{ml})$ and EGF $(5 \mathrm{ng} / \mathrm{ml})$ for 8 days. Under these conditions there was extensive proliferation accompanied by a minority population that spontaneously formation of red and blue-staining foci (see arrows), indicative of early stages of keratinizing differentiation. Figure 7(f) shows a similar monolayer of A431 cells also grown for 12 days in DMEM supplemented insulin $(5 \mathrm{ug} / \mathrm{ml})$ and EGF $(5 \mathrm{ng} / \mathrm{ml})$. The culture has attained a higher cell density. Under these prolonged culture conditions, there is now no evidence now of spontaneous formation of red or blue staining foci.

\subsection{SCC-25 Cells Fail to Undergo Induced Differentiation under Growth Factor-Depleted Serum-Free Culture Conditions}

Figure 8 presents an immune-fluorescent microscopic image of a culture of SCC25 cells switched from DMEM-10\% FCS medium at low density and cultured for 7 days in MCDB153 SFM lacking growth factors. The entire monolayer of SCC25 cells stains positive with BK monoclonal antibody, and instead continue to proliferate. Figure 9(a) is a DNA flow cytofluorometric analysis of a confluent cell culture of SCC25 cells growth-arrested in the $\mathrm{G}_{1}$ phase of the cell cycle ( $\left.>65 \%\right)$. Nevertheless, such cultures fail to undergo spontaneous commitment to differentiation (see Figure 8). By contrast, Figure 9(b) presents the FMF prolife of a low-density proliferating culture. The DNA prolife shows $54 \%$ of the cells in $\mathrm{G}_{1}$ typical of proliferating cells.

\subsection{Summary of Culture and Growth Factor Media Shifting Results}

The differentiating effects of media and growth factors on NHK cells and three different epidermoid carcinoma cell lines are summarized in Table 1. Both HeLa and KB cells differs from NHK in failing to differentiate in high calcium MCDB153 medium lacking protein growth factors, but are induced to differentiate in low calcium serum-free MCDB153 medium supplemented with EGF and insulin. By contrast, A431 cells differentiate in both low and high calcium MCDB153 medium lacking EGF and insulin, but undergo very minimal differentiation in high calcium DMEM medium supplemented with EGF and insulin. SCC-25 cells undergo senescent high density $\mathrm{G}_{1}$ type growth arrest in serum-free media condition lacking growth factors without subsequent terminal differentiation.

\subsection{Evidence for Quantal-Type Mitosis in Hela and SCC-25 Epidermoid Carcinoma Cells}

An unexpected observation in HeLa cell cultures undergoing media induced differen- 
tiation was a frequency of a red-stained cell paired with a blue-stained cell (see Figure 3(c) and Figures 3(d)). A possible explanation for this observation is that quantal mitosis occurs following induction of differentiation. As reported above, microscopic analysis of cells shown in Figure 4(c) shows that there were an almost equal number of
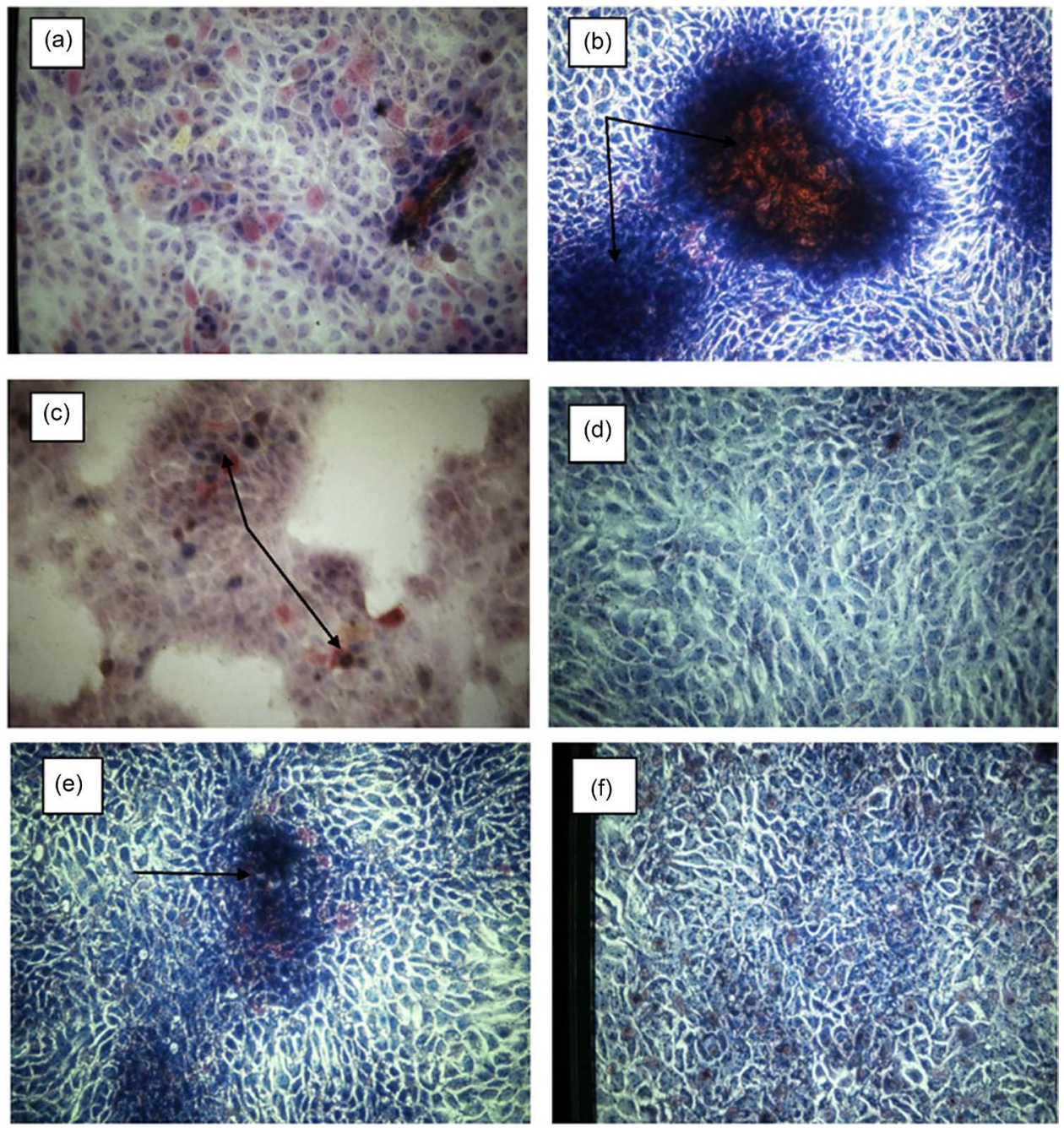

Figure 7. A431 cells cultured in DMEM-10\% FCS for 5 days (a) and (b) for 12 days, respectively. Note: dispersed blue-stained and red-stained cells in (a), and (b) large foci (crown) of stratified red-stained cells surrounded by a monolayer field of blue-stained undifferentiated cells (see arrows), a condition reminiscent of NHK cells undergoing induced keratinizing differentiation (see Figure 2); (c) A431 cells cultured for 3 days in DMEM medium without serum after transfer from growth in serum-containing medium. Note: single red-stained cells located in the interior of the colony (see arrows); (d) a confluent culture of A431 cells grown in DMEM medium lacking serum or protein growth factors for 8 days after transfer from growth and in a serum-containing media. Note: the monolayer cells are all undifferentiated cells that stain blue: (e) a confluent culture of A431 cells cultured for 8 days in DMEM media supplemented with insulin $(5 \mathrm{ug} / \mathrm{ml})$ and EGF ( $5 \mathrm{ng} / \mathrm{ml}$ ). Note: arrows indicate areas of red-and blue stained stratifying foci of early stage differentiation; (f) A431 cells cultured for 12 days in DMEM medium supplemented with insulin ( $5 \mathrm{ug} / \mathrm{ml}$ ) and EGF $(5 \mathrm{ng} / \mathrm{ml}$ ) that are stained blue yet fail to undergo induced keratinizing differentiation. All cultures were fixed and stained with KP stain (see Methods). 


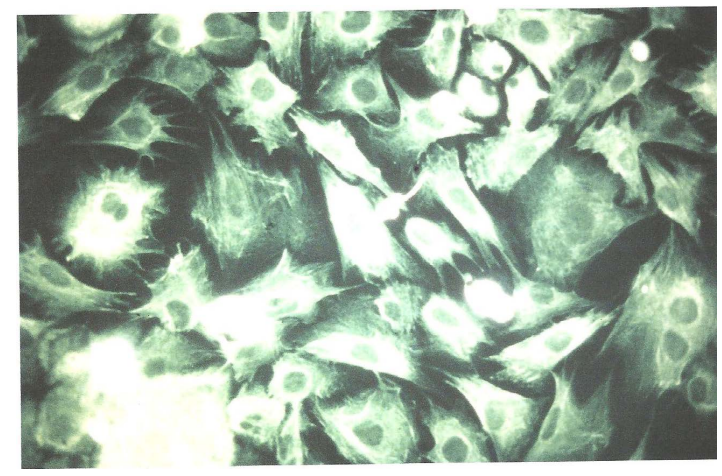

Figure 8. An immunofluorescent microscope image of a culture of SCC25 cells stained positively for keratin protein $\mathrm{KB}$ antibody specific for undifferentiated keratinocytes. Note: larger cells are less positive than smaller cells.

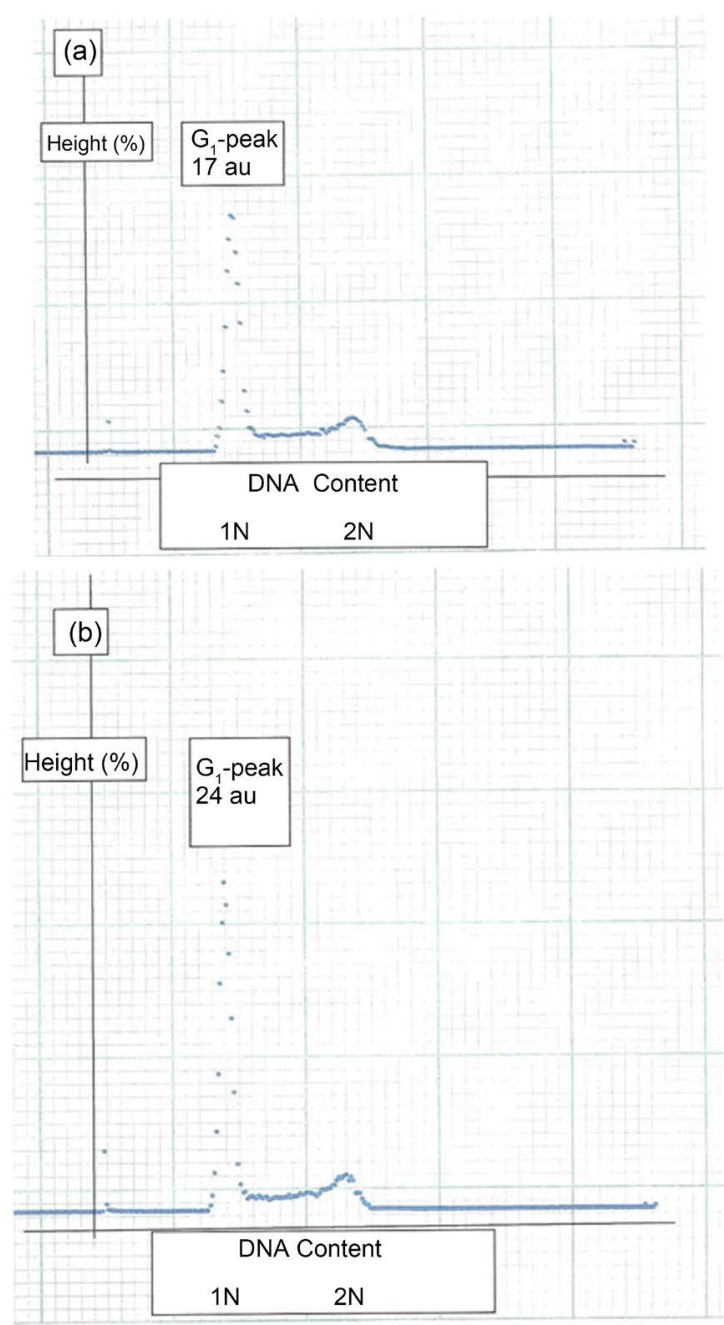

Figure 9. Microfluorometric (FMF) profiles of DNA contents for: (a) proliferating SCC25 cells and (b) DNA content profiles of confluent-arrested SCC25 cells. Ordinate: percent of cells (\%), height. Abscissa: DNA contents: $1 \mathrm{~N}$, DNA content of cells before duplication, and 2N, DNA content after duplication. SCC25 cells were cultured in DMEM-10\% FCS. Note: $G_{1}$ peak in (b) is greater (24 arbitrary units, au) than in (a) (17 arbitrary units, au) as shown by text boxes. 
Table 1. Serum-free culture conditions for induction of keratin protein stain surrogate expression: normal compared to several epidermoid carcinoma cell lines.

\begin{tabular}{ccccc}
\hline & $\begin{array}{c}\mathrm{GF}^{-} \\
\left(\text {Low } \mathrm{Ca}^{2+}\right)^{\mathrm{b}}\end{array}$ & $\begin{array}{c}\mathrm{GF}^{-} \\
\left(\mathrm{High} \mathrm{Ca}^{2+}\right)^{\mathrm{c}}\end{array}$ & $\begin{array}{c}\mathrm{GF}^{+} \\
\left(\mathrm{Low} \mathrm{Ca}^{2+}\right)^{\mathrm{d}}\end{array}$ & $\begin{array}{c}\mathrm{GF}^{+} \\
\left(\mathrm{High} \mathrm{Ca}^{2+}\right)^{\mathrm{e}}\end{array}$ \\
\hline $\mathrm{NHK}^{\mathrm{a}}$ & - & + & - & + \\
$\mathrm{HeLa}$ & - & - & + & + \\
$\mathrm{KB}$ & - & - & + & + \\
$\mathrm{A} 431$ & + & - & nd & + \\
\hline
\end{tabular}

a: Entries are based on previously published data [23]. $\mathrm{GF}^{-}$: growth factor negative; $\mathrm{GF}^{+}$: growth factor positive. Nd: not done; b: MCDB153/DMEM serum-free medium containing $0.1 \mathrm{mM}$ calcium lacking protein growth factors; c:, MCDB153/DMEM serum-free medium containing $2 \mathrm{mM}$ calcium lacking protein growth factors; d: MCDB153/DMEM serum-free medium containing $0.1 \mathrm{mM}$ calcium supplemented with EGF $(5 \mathrm{ng} / \mathrm{ml})$ and insulin $(5 \mu \mathrm{g} / \mathrm{ml})$; e: MCDM153/ DMEM serum-free medium containing $2 \mathrm{mM}$ calcium supplemented with EGF $(5 \mathrm{ng} / \mathrm{ml})$ and insulin $(5 \mu \mathrm{g} / \mathrm{ml})$.

red $(\mathrm{N}=52)$ and blue cells $(\mathrm{N}=48)$, a result expected if they all originated from 50 mother cells that underwent a quantal-type mitotic division under induced commitment to terminal differentiation. Direct evidence for quantal-type mitosis was observed when a high cell density cultures of SCC25 that stains only blue with the KP stain (Figure 10(a)) when grown in DMEM:F12-5\% FCS media was shifted to low clonal cell density (500 cells $/ \mathrm{cm}^{2}$ ) and cultured in DMEM:F12-5\% FCS for 2 days, fixed and stained with KP stain. Figures 10(b) and Figures 10(c) show several different red-blue pairs that arose from mother cells that underwent a quantal mitotic division. A more definitive proof of quantal type mitosis was obtained by combining autoradiography with KP straining. Figure 10(d) shows such a red-blue pair from a low density clonal growth culture of SCC25 in which the red-stained cell nucleus is unlabeled and the blue stained cell nucleus is labeled with $\left[{ }^{3} \mathrm{H}\right]-\mathrm{TdR}$ as expected for the outcome of a quantal type mitosis.

\section{Discussion}

A critical difference between cancer cells and normal cells is their lack of differentiation

[1] [11]. Malignant tumors appear to be a mixture of both normal-looking cells and more differentiated looking cells. When malignant carcinoma cells are cultured in vitro, there is an increased proportion of rapidly growing undifferentiated cells and a lesser proportion of slowly proliferating cells that undergo spontaneous differentiation mimicking the in vivo tumor population. In this report, we have investigated the effect of protein growth factors and media composition that can shift the balance between proliferation and differentiation in favor of commitment to terminal differentiation.

Table 1 summarizes the differentiating effects of media and growth factors on NHK cells relative to three different epidermoid carcinoma cell lines. Both HeLa and $\mathrm{KB}$ cells differ from NHK in failing to differentiate in high calcium MCDB153 medium lacking protein growth factors, but are induced to differentiate in low calcium serum-free MCDB153 medium supplemented with EGF and insulin. By contrast, A431 cells differentiate in both low and high calcium MCDB153 medium lacking EGF and insulin, but 

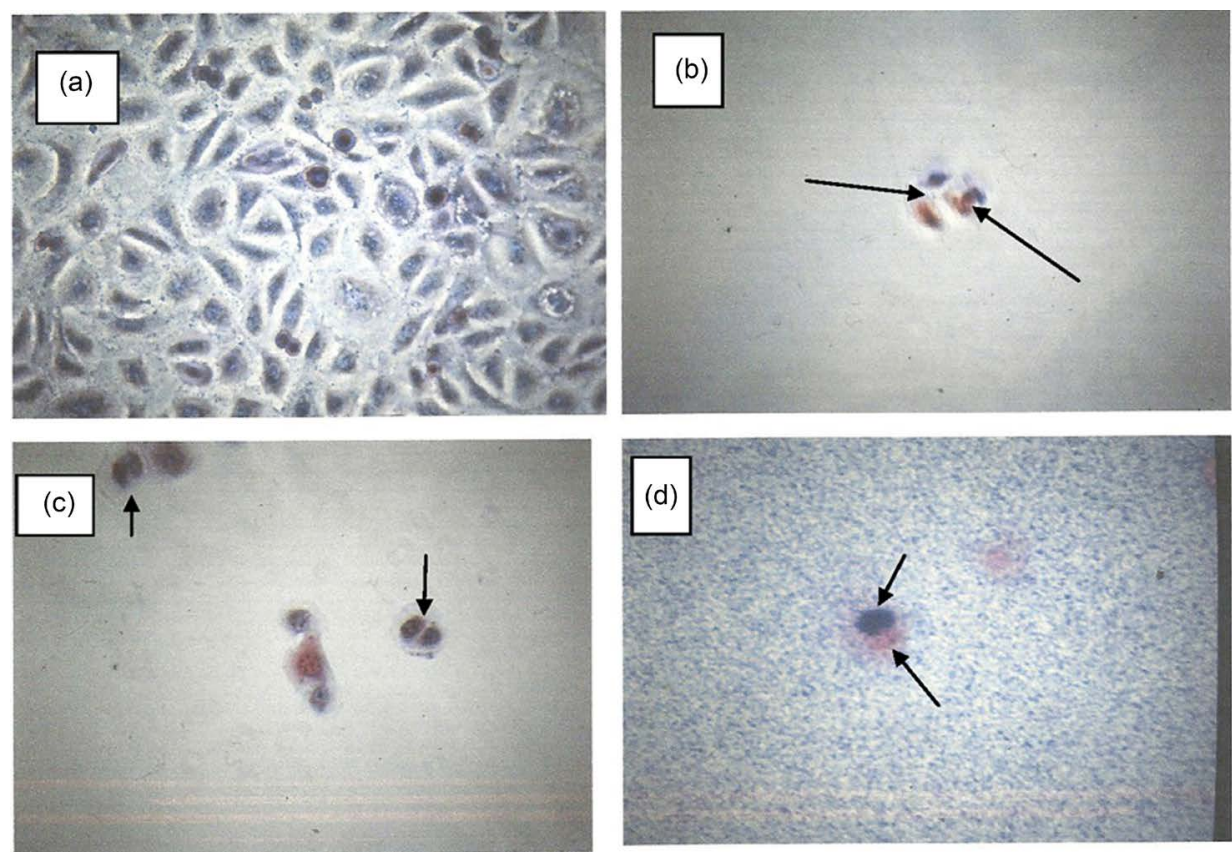

Figure 10. SCC cells were cultured in DMEM: F12-5\% FCS. (a) confluent monolayer stains all blue. (b) and (c) SCC cells were reseeded at low cell density from a post-confluent monlayer grown in DMEM-10\% FCS medium (arrows point to red-blue pairs). (d) an autoradiograph showing SCC-25 cell undergoing post-mitotic division. Note: one cell of the pair is blue (see top arrow) and labelled with Tritium grains while the other member of the pair stain red and is unlabelled with Tritium grains (see bottom arrow). All cultures were stained with the KP stain (see Methods).

fail to undergo differentiation in high calcium DMEM medium supplemented with EGF and insulin. Earlier [12], it was reported that EGF treatment of A431, and clonal variants with high levels of EGF receptors inhibited cell growth. Their phase microscopic images of EGF-induced growth arrest of A431 and two clonal variants, CL29 and CL4, show "dense clusters which contained multiple cell layers", which we here reinterpret in the light of our KP staining as foci of cellular differentiation. These same changes in morphology induced in A431 cells by EGF inhibition were observed earlier [13].

We found that serum-free media contain EGF and millimolar concentrations of calcium-induced differentiation in HeLa, KB and A431 cells. Taken together, these results support the notion that epidermoid carcinoma cells retain the ability to initiate and progress toward terminal squamous stratified and keratinizing differentiation when induced by appropriate commitment signals. Commitment signals are themselves linked to conditions that lead to $\mathrm{G}_{1}$-dependent growth arrest. For A431 cells, we found that induction of differentiation was coupled with high cell density growth arrest in the $\mathrm{G}_{1}$ phase of the cell cycle. Further, we reported earlier that $\mathrm{G}_{1}$-dependent growth arrest was a precondition for differentiation of NHK cells [8] [14]-[16]. In agreement with an earlier study [4], we found that SSC-25 cells failed to undergo terminal differentiation in high calcium-low growth factor serum-free medium. Nevertheless, SCC-25 cells do 
commit to differentiation via production of quantal mitotic division pairs when shift from high cell density to low density cultures in a serum-containing medium.

In review, we note that many studies have focused on the use of chemopreventive and chemotherapeutic agents to reverse the cancer cell phenotype. Earlier studies [17] on murine erythroleukemia reported that many active agents were able to induce cell differentiation among which were polar compound (e.g., dimethylsulfoxide), purines and purine derivatives (hypoxanthine and 2,6-diaminopurine), antitumor agents (5-fluoruracil, Adriamycin, cytosine arabinoside and hydroxyurea), and methylisobutyl xanthine. Retinoic acid (RA) is among the best known of these agents. Retinoid chemotherapy has been employed clinically for treatment of prostate and bladder cancers, induces differentiation of mouse and human melanoma cells [18], reverses hamster tracheal epithelial metaplasia induced by vitamin A-deficiency [19], inhibits tumor promoter induced ornithine decarboxylase enzyme, and prevents papilloma formation in the two-stage mouse model of skin carcinogenesis [20]. It requires a two-three log higher concentration of trans-retinoic acid to inhibit proliferation than for normal keratinocytes ("unpublished data"). Unfortunately, the therapeutic index of the most effective retinoids leaves little room for their use in normalizing cancer cell differentiation phenotype in vivo.

We report here for the first time that the commitment to differentiation in two epidermoid carcinoma cell lines, SCC25 and HeLa, appears to be linked by a preceding quantal-type mitotic division. The occurrence of quantal cell cycle was defined by Holtzer et al. [21] as "cell cycles leading to cells with new pathways". This is certainly true for HeLa, KB and SCC25 tumor keratinocytes that leave the proliferative cell cycle and begin synthesis of keratin proteins as described here. Our experimental results can be reframed as supportive of the research of Pierce [22] [23], who first demonstrated normalization of a neuroblastoma cancer cells by inducing normal neural differentiation to occur when they are transplanted into the blastocyst of mice. Pierce and Wallace [24] also quoted several medical examples where malignant cells became benign including the spontaneous differentiation of human neuroblastoma into benign ganglioneuromas, and the modulating effect of vitamin A on squamous carcinoma. We hope our studies will challenge others to normalize cancer tissues in situ through strategies that employ growth factor-induced cell cycle-dependent growth arrest in the immediate growth environment of malignant tumors.

\section{Acknowledgements}

We thank Dr. Robert E. Scott then at the Mayo Clinic, Rochester, MN for gift of the cryopreserved epidermoid carcinoma cell lines. This work was supported by PO1CA340968 to Biochemistry Department, Sloan-Kettering Division, Southern Research Institute, Birmingham, AL.

\section{References}

[1] Weinberg, R.A. (2007) The Biology of Cancer Garland Science. Taylor \& Francis Group, 
LLC, New York, NY.

[2] Steinberg, M.L. and Defendi, V. (1979) Altered Pattern of Growth and Differentiation in Human Keratinocytes Infected by Simian Virus 40. Proceedings of the National Academy of Sciences of the United States of America, 76, 801-805. http://dx.doi.org/10.1073/pnas.76.2.801

[3] Ayoub, P. and Shklar, G. (1963) A Modification of the Mallory Connective Tissue Stain as a Stain for Keratin. Oral Surgery, 16, 581. http://dx.doi.org/10.1016/0030-4220(63)90148-8

[4] Scott, R.E., Wilke, M.S., Wille Jr., J.J., Pittelkow, M.R., Hsu, B.M. and Kasperbauer, J.L. (1988) Human Squamous Carcinoma Cells Express Complex Defects in the Control of Proliferation and Differentiation. The American Journal of Pathology, 133, 374-380.

[5] Fusenig, N.E., Breitkreutz, D., Dzarlieva, R.T., Bukamp, P., Bohnert, A. and Tilgen, W. (1983) Growth and Differentiation Characteristics of Transformed Keratinocytes from Mouse and Human Skin in Vitro and in Vivo. Journal of Investigative Dermatology, 81, 168s-175s. http://dx.doi.org/10.1111/1523-1747.ep12541032

[6] Wille, J.J. and Scott, R.E. (1986) Suppression of Tumorigenicity in Cell Cycle-Dependent Control of Cellular Differentiation and Proliferation. International Journal of Cancer, 37, 875-881. http://dx.doi.org/10.1002/ijc.2910370613

[7] Pittelkow, M.R., Wille, J.J. and Scott, R.E. (1986) Two Functionally Distinct Classes of Growth Arrest States in Human Prokeratinocytes That Regulate Clonogenic Potential. Journal of Investigative Dermatology, 86, 410-417. http://dx.doi.org/10.1111/1523-1747.ep12285684

[8] Wille, J.J., Pittelkow, M.R., Shipley, G.D. and Scott, R.E. (1984) Integrated Control of Growth and Differentiation of Normal Human Prokeratinocytes Cultured in Serum-Free Medium: Clonal Analyses, Growth Kinetics, and Cell Cycle Studies. Journal of Cellular Physiology, 121, 31-44. http://dx.doi.org/10.1002/jcp.1041210106

[9] Wille, J.J., Burdge, J.J. and Pittelkow, M.R. (2011) Rapid Healing of Chronic Venous Stasis Leg Ulcers Treated by the Application of a Novel Serum-Free Cultured Autologous Epidermis. Wound Repair and Regeneration, 19, 464-474. http://dx.doi.org/10.1111/j.1524-475X.2011.00702.x

[10] Dean, P.N. and Jett, J.H. (1974) Mathematical Analysis of DNA Distributions Derived from Flow Microfluorimetry. The Journal of Cell Biology, 60, 523-527. http://dx.doi.org/10.1083/jcb.60.2.523

[11] Rudden, R. (1981) Cellular Differentiation and Cancer. In: Rudden, R., Ed., Cancer Biology, Oxford University Press, New York, 99-119.

[12] Chinkers, M., McKanna, J.A. and Cohen, S. (1981) Rapid Rounding of Human Epidermoid Carcinoma Cells A431 Induced by Epidermal Growth Factor. The Journal of Cell Biology, 88, 422-429. http://dx.doi.org/10.1083/jcb.88.2.422

[13] Lifschitz, A., Lazar, C.S., Buss, J.E. and Gill, G.N. (1983) Analysis of Morphology and Receptor Metabolism in Clonal Variant A431 Cells with Differing Growth Responses to Epidermal Growth Factor. Journal of Cellular Physiology, 115, 235-242. http://dx.doi.org/10.1002/jcp.1041150304

[14] Scott, R.E., Hoerl, B.J., Wille, J.J., Florine, D.L., Krawisz, B.R. and Yun, K. (1982) Coupling of Proadipocyte Growth Arrest and Differentiation. II. A Cell Cycle Model for the Physiological Control of Cell Proliferation. The Journal of Cell Biology, 94, 400-405. http://dx.doi.org/10.1083/jcb.94.2.400

[15] Scott, R.E., Florine, D.L., Wille, J.J. and Yun, K. (1982) Coupling of Growth Arrest and Differentiation at a Distinct State in the $\mathrm{G}_{1}$ Phase of the Cell Cycle: $\mathrm{G}_{\mathrm{D}}$. Proceedings of the Na- 
tional Academy of Sciences of the United States of America, 79, 845-849. http://dx.doi.org/10.1073/pnas.79.3.845

[16] Wilke, M., Hsu, B., Wille Jr., J.J., Pittelkow, M.R. and Scott, R.E. (1988) Biologic Mechanisms for the Regulation of Normal Human Keratinocyte Proliferation and Differentiation. The American Journal of Pathology, 131, 171-181.

[17] Marks, P.A. and Rifkin, R.A. (1978) Erythroleukemic Differentiation. Annual Review of Biochemistry, 47, 419. http://dx.doi.org/10.1146/annurev.bi.47.070178.002223

[18] Lotan, R., Neumann, G. and Lotan, D. (1981) Characterization of Retinoic Acid-Induced Alterations in the Proliferation and Differentiation of a Murine and a Human Melanoma Cell lIne in Culture. Modulation of Cellular Interactions by Vitamin A and Derivatives (Retinoids), Annals of the New York Academy of Sciences, 359, 150-170. http://dx.doi.org/10.1111/j.1749-6632.1981.tb12744.x

[19] Wille, J.J. and Chopra, D. (1988) Reversal by Retinoids of Keratinization Induced by Benzo $[\alpha]$ pyrene in Normal Hamster Tracheal Explants: Comparison with the Assay Involving Organ Cultures of Tracheas from Vitamin A-Deficient Hamsters. Cancer Letters, 40, 235246. http://dx.doi.org/10.1016/0304-3835(88)90082-1

[20] Verma, A.K., Shapas, B.G., Rice, H.M. and Bojtwell, R.K. (1979) Correlation of the Inhibition by Retinoids of Tumor Promoter-Induced Mouse Epidermal Ornithine Decarboxylase Activity and of Skin Tumor Promotion. Cancer Research, 39, 419-425.

[21] Holzer, H., Schultheiss, T., Dilullo, C., Choi, J., Costa, M., Lu, M. and Holtzer, S. (1990) Autonomous Expression of the Differentiation Programs of Cells in the Cardiac and Skeletal Myogenic Lineages. Annals of the New York Academy of Sciences, 599, 158-169. http://dx.doi.org/10.1111/j.1749-6632.1990.tb42374.x

[22] Pierce, G.B. (1970) Differentiation of Normal and Malignant Cells. Federation of American Societies for Experimental Biology, 29, 1248-1254.

[23] Pierce, G.B., Aguilar, D., Hood, G. and Wells, R.S. (1984) Trophectoderm in Control of Murine Embryonal Carcinoma. Cancer Research, 44, 3987-3996.

[24] Pierce, G.B. and Wallace, C. (1971) Differentiation of Malignant to Benign Cells. Cancer Research, 31, 127-134.

\section{Submit or recommend next manuscript to SCIRP and we will provide best service} for you:

Accepting pre-submission inquiries through Email, Facebook, LinkedIn, Twitter, etc. A wide selection of journals (inclusive of 9 subjects, more than 200 journals)

Providing 24-hour high-quality service

User-friendly online submission system

Fair and swift peer-review system

Efficient typesetting and proofreading procedure

Display of the result of downloads and visits, as well as the number of cited articles

Maximum dissemination of your research work

Submit your manuscript at: http://papersubmission.scirp.org/

Or contact jet@scirp.org 